\title{
$\bullet$ \\ Micro-Algal Diet for Copepod Culture with Reference to Their Nutritive Value - A Review
}

\author{
IJCRR \\ Section: Healthcare \\ ISI Impact Factor \\ (2019-20): 1.628 \\ IC Value (2019): 90.81 \\ $\operatorname{SJIF}(2020)=7.893$ \\ (c) (7) (8) \\ Copyright@IJCRR
}

Altaff K, Vijayaraj R

Department of Marine Biotechnology, AMET University, Chennai-6o3112, India.

\section{ABSTRACT}

Cultured copepods have been successfully used in the larviculture of various finfish larvae. Over the past few years, there have been several research articles published on copepod culture to cater to the needs of aqua hatcheries and discussed the important role of copepods as suitable feeds for marine finfish larviculture. However, the upscaling of copepod cultures to the commercial level is still a challenge. In this regard, the present review is focused on the culture of copepod utilizing various micro-algal diets with single or in combination with multiple species, and evaluation of nutritional importance of copepods for finfish larviculture. Therefore, the review article paves the way to improve the nutrition in copepod culture through ideal micro-algae andutilization in aqua hatcheries for better results in terms of larval performance in finfish larval rearing.

Key Words: Copepods, Micro-algae, Larviculture, Aquaculture, Nutrients, Finfish

\section{INTRODUCTION}

Hatchery rearing of commercially important finfish and shellfish larvae is important for successful farming of these species and live feed plays a vital role in this regard. ${ }^{1-3}$ Live feeds are phytoplankton and zooplankton. They constitute the main component of the diet for finfish and shellfish larvae especially marine finfish. They are referred to as living capsules of nutrition because they contain essential nutrients such as proteins, lipids, carbohydrates, vitamins, minerals, amino acids and fatty acids. ${ }^{4}$ In marine aquaculture, the use of live feed can't replace by formulated diets in some cases. Artemia nauplii and rotifers (Brachionus plications) are still the most commonly used live feed. A good alternative is the use of copepods for rearing finfish larvae with small Gabe which could lead to the cultivation of new finfish species. ${ }^{5,6}$ Based on the above rationale, the present review article discusses the utilization of a micro-algae diet for copepods larviculture. Most research on copepods have focused on their nutrition, reproduction or physiological aspects, and culture techniques using micro-algae culture have primarily been developed at the laboratory scale.

\section{NEED FOR ALTERNATIVE LIVE FEEDS}

Past few decades, the marine hatcheries are largely dependent on the production of rotifers and brine shrimp as they could be cultured successfully and offered as traditional live feeds for fish and crustacean larvae. ${ }^{7-10}$ Rotifers are relatively easy to culture and can rapidly achieve high culture densities. ${ }^{11}$ Artemia can be obtained commercially in the form of dry cysts and their nauplii exhibit a good tolerance to culture conditions and handling. ${ }^{12}$ Research focusing on the identification of alternative feed sources that overcome the inadequacies of traditional rotifer and Artemia live feeds is critical to increase the variety and survival of species that can be successfully cultivated, and ultimately enhance the growth, sustainability and economic performance of the aquaculture industry. ${ }^{13-16}$ Copepods appear to be the most valuable candidate for this role as they are the most important natural prey for a vast majority of marine finfish larvae ${ }^{16-19}$ and their inclusion as live prey in larviculture may increase the number of fish species that can be successfully reared. Table 1 summarize the size range and main nutritional characteristics of copepods compared to the rotifers and Artemialive feed. Copepod nauplii are

\section{Corresponding Author:}

Dr. K. Altaff, Professor, Department of Marine Biotechnology, AMET University, Chennai-603112, India.

Mobile: (+91)-9444108110; ORCID: https://orcid.org/0000-0001-9178-2519; Email: kaltaff@gmail.com

ISSN: 2231-2196 (Print)

ISSN: 0975-5241 (Online)

Received: 25.08 .2020

Revised: 04.11 .2020

Accepted: 17.12 .2020

Published: 12.04 .2021 
generally smaller than the smallest strain of rotifers and $\mathrm{Ar}$ temia nauplii, and higher levels of the major nutrient also indicated when compared to enriched rotifers and Artemia nauplii. ${ }^{20-23}$

\begin{tabular}{|c|c|c|c|c|c|c|}
\hline \multirow{2}{*}{$\begin{array}{l}\text { Name of the Live } \\
\text { feeds }\end{array}$} & \multirow{2}{*}{$\begin{array}{l}\text { Size } \\
\text { range }\end{array}$} & \multicolumn{4}{|c|}{ Main Nutrients characteristics } & \multirow[t]{2}{*}{ Reference } \\
\hline & & Major nutrients & HUFA & $\begin{array}{l}\text { DHA/ } \\
\text { EPA }\end{array}$ & Lipids & \\
\hline Artemia nauplii & $\begin{array}{l}400- \\
500 \mu \mathrm{m}\end{array}$ & $\begin{array}{l}\text { Insufficient (enrich- } \\
\text { ment needed) }\end{array}$ & Very low & $<1 \%$ & $\begin{array}{l}\text { Mostly triacyglycerols } \\
\text { (enrichment needed) }\end{array}$ & $24-28$ \\
\hline Rotifer & $\begin{array}{l}\sim 100- \\
150 \mu \mathrm{m}\end{array}$ & $\begin{array}{l}\text { Insufficient (enrich- } \\
\text { ment needed) }\end{array}$ & Low & $<1 \%$ & $\begin{array}{l}\text { Mostly triacyglycerols } \\
\text { (enrichment needed) }\end{array}$ & $29-31$ \\
\hline Copepod nauplii & $<8 \mathrm{o} \mu \mathrm{m}$ & $\begin{array}{l}\text { Higher-level com- } \\
\text { pared to Artemia and } \\
\text { rotifer }\end{array}$ & $\begin{array}{l}\text { Naturally } \\
\text { high level }\end{array}$ & $\begin{array}{l}>1 \% \text { higher } \\
\text { levels of DHA } \\
\text { and EPA when } \\
\text { compared to } \\
\text { rotifers and } \\
\text { Artemia }\end{array}$ & $\begin{array}{l}\text { More phospholipids }(>50 \%) \\
\text { when compared to Artemia } \\
\text { and rotifers }\end{array}$ & $\begin{array}{c}3,12,22,32, \\
33,34,35\end{array}$ \\
\hline
\end{tabular}

For the past three decades, there has been continuing interest in the development of mass culture techniques for copepods to be used as live food in aquaculture. ${ }^{3,7}$ Copepods are the most common metazoans in the marine environment, with approximately 11,500 described species. Unlike traditional live feed, copepod nutritional profiles are rich in essential fatty acids, free amino acids and other essential micronutrients. ${ }^{13}$ Moreover, the small size of copepod nauplii is vital for the first larval feeding of various fish species (Table 2).

The copepod cultivation methods establishment with costeffective protocols for mass production is still a challenge. Copepods have mostly been used at a pilot-scale or in locations where the abundant collection of natural zooplankton is possible. Still, the use of copepods as live feeds for marine fish larvae has generally led to considerably better results in terms of larval performance and quality, when compared with rotifers and Artemia nauplii. ${ }^{9}$ The copepod nauplii may be produced in the rearing tanks or separate tanks and ponds. It has also been proposed that mass production of copepod resting eggs could facilitate the availability of copepod nauplii for aquaculture. However, research is needed on storage conditions of resting eggs concerning the survival and nutritional value of nauplii. . $^{18,36-38}$

\section{UTILIZATION OF MICRO-ALGAL DIET FOR CO- PEPODS LARVICULTURE}

In aquaculture, micro-algae are used as a direct food source for various filter-feeding larval stages of organisms. They are also used as an indirect food source, in the production of copepod culture which in turn is used as food for the carnivorous larvae of many of the marine finfish species presently farmed. ${ }^{39-41}$ The intensive rearing of bivalves has so far relied on the production of live micro-algae, which comprises on average $30 \%$ of the operating costs in a bivalve hatchery. For culture of marine finfish larvae according to the green water technique the micro-algae are used directly in the larval tanks. ${ }^{42}$ This technique is nowadays a normal procedure in marine larviculture. It has been widely reported to improve fish larval growth, survival and feed ingestion which showed that micro-algae seemed to provide nutrients directly to the larvae that contribute to nutritional quality as it plays an important role in the microflora diversification of both the tank and the larval gut. ${ }^{22}$ Whenever micro-algae are used as a direct food source or indirect food source in the production of copepods, the growth of the animals is usually superior when a mixture of several microalgal species is used. The microalgae diets of copepods culture are listed in Table 2.

\section{NUTRITIONAL IMPORTANCE OF MICRO-ALGAE}

Increasing the needs for protein and the high cost of fish meal in recent years has led to the search for new alternatives, as animal and plant sources of protein for sustainable aquaculture. ${ }^{42}$ One such accessible and relatively inexpensive food component that could respond successfully to the challenging question raised by aquaculture is algae. Cultivation of microalgae is mandatory in hatchery as it is a basic and nutritious diet for live feed organisms, specifically the zooplankton. ${ }^{91}$ However, factors such as manpower requirement, infrastructure facilities and other related costs 
involved in the high-density culture escalate the price of the production. For the cost-effective production of micro-algae, new approaches have to be adopted with an improvised culture environment. Micro-algal species can vary significantly in their nutritional value, and this may also change under different cultural conditions. ${ }^{92,93}$

In the laboratory-scale production of micro-algae, light plays a fundamental role in the development of microalgae through photosynthesis. ${ }^{94,95} \mathrm{It}$ is one of the major environmental factors which control the performance of micro-algae through phototrophic growth and productivity. However, the extreme light intensity may result in photoinhibition which reduces the photosynthetic rates and growth. In the indoor culture based on the light-dark cycle periodicity duration of L D 12: 12 illumination, it could be modified to $14: 10 \mathrm{~L} \mathrm{D}$ or a maximum of 16:8 LD for optimizing photosynthesis of microalgae For some microalgae and diatoms it has been reported that changes in the frequency of light-dark cycle enhance exponentially rate of photosynthesis. Some aquaculture hatcheries adopt a longer dark period compared to the light period for enhancing photosynthetic competence..$^{96-99}$

Many algae have been found to contain good nutritional properties. Several factors can contribute to the nutritional value of a micro-alga, which include their size and shape, digestibility, biochemical composition, nutrients profile and enzymes. These factors satisfy the nutritional requirements of the larvae feeding on the algae. Many studies have attempted to correlate the nutritional value of micro-algae with their biochemical and nutritional profile. ${ }^{100-101}$ In the primary growth phase of the micro-algae, they contain 30 to $40 \%$ protein, 10 to $20 \%$ lipid and 5 to $15 \%$ carbohydrate ${ }^{51}$ and the high dietary protein provided the best growth for Oithona davisae. ${ }^{102}$ The major nutritional composition (Carbohydrates, Protein and Lipid) of some commercially important micro-algal species is comparable with the available feed ingredients which are used in the aquafeed.

For the supply of sufficient nutrient for primary and secondary consumers, micro-algae should have the nutrient profile of protein (6-52\%), carbohydrate (5-23\%) and lipid (7-23\%). Most microalgal species have a similar amino acid composition with enriched essential amino acids and high concentrations of ascorbic acid (1-16 $\mathrm{mg} \mathrm{g}^{-1}$ dry weight) and riboflavin $\left(20-40 \mu \mathrm{g} \mathrm{g}^{-1}\right) \cdot{ }^{103}$ Further high percentage of nutrient contents, carbohydrates, proteins and lipids were recorded in common micro-algae. ${ }^{104-109}$ Microalgal protein could be a plausible alternative to fishmeal protein because of its desired quality and amino acid profiles comparable with that of other reference protein sources. ${ }^{109}$ There are several studies on the utilization of biomass of Arthrospira sp. ${ }^{110}$, Chlorella sp. ${ }^{111}$ Scenedesmus sp. ${ }^{112}$ Nanofrustulum sp. ${ }^{113}$ and Tetraselmissuecica ${ }^{114}$ as valuable supplementary protein sources.
Lipids have a role as high energy storage molecules. Oil content in micro-algae can exceed $60 \%$ by weight of dry biomass, while levels of 20 to $50 \%$ are common. PUFAs derived from micro-algae such as docosahexaenoic acid (DHA), eicosapentaenoic acid (EPA) and arachidonic acid (AA) are known to be essential bioactive molecules for various larval cultures. ${ }^{115}$ Dunstan et al. ${ }^{116}$ reported the most micro-algal species to have moderate to high percentages of EPA ( 7 to $34 \%$ ) as in the case of major micro-algae species such as Pavlova spp. and Isochrysis sp. A high amount of DHA (0.2 to $11 \%$ ) is present inNannochloropsis spp. and diatoms consisting of the highest percentages of AA (4\%).

Vitamins are essential micronutrients and their content can vary in different micro-algae. Brown and Miller ${ }^{117}$ reported that ascorbic acid shows the greatest variation ( 1 to $16 \mathrm{mg}$ $\left.\mathrm{g}^{-1}\right)$ in different micro-algae. The $\beta$-carotene content ranged from 0.5 to $1.1 \mathrm{mg} \mathrm{g}^{-1}$. The vitamin $\mathrm{B}$ complex is rich in micro-algae and amount of different compounds of this vitamin showed variation in their levels (thiamin 29 to $109 \mu \mathrm{g}$ $\mathrm{g}^{-1 ;}$ riboflavin 25 to $50 \mu \mathrm{g} \mathrm{g}^{-1}$; niacin (0.11 to $0.47 \mathrm{mg} \mathrm{g}^{-1}$; pantothenic acid 14 to $38 \mu \mathrm{g} \mathrm{g}^{-1}$; pyridoxine 3.6 to $17 \mu \mathrm{g} \mathrm{g}^{-1}$; biotin 1.1 to $1.9 \mu \mathrm{g} \mathrm{g} \mathrm{g}^{-1}$; folates 17 to $24 \mu \mathrm{g} \mathrm{g}^{-1}$; cobalamin 1.8 to $\left.7.4 \mu \mathrm{g} \mathrm{g}^{-1}\right)$. The $\alpha$-tocopherol content of micro-algae ranged between 0.07 and $0.29 \mathrm{mg} \mathrm{g}^{-1}$.

\section{NUTRITIONAL IMPORTANCE OF COPEPODS}

Copepods can consume different unicellular micro-algae and also capable of feeding on filamentous algae which might provide all necessary nutrients. Several studies have demonstrated correlations between zooplankton productions and some amino acids and fatty acids content in dietary algae. ${ }^{118}$ The free-living copepod nauplii more particularly those of harpacticoid are highly suitable starter feed for marine finfish larvae due to their small size and nutritive value. The larvae of dolphinfish(Coryphaenahippurus) fed with harpacticoid copepod (Euterpinaacutifrons) nauplii showed desirable growth, survival and biochemical profile in the hatchery rearing. The mass culture system using micro-algae for the production of benthic marine harpacticoid copepod described by Sun and Fleeger could be an ideal starter feed for rearing larvae of many marine finfish with small mouth size. ${ }^{119}$

The high content of lipid is reported from many marine copepods and docosahexaenoic acid (DHA; 22:6n-3), eicosapentaenoic acid (EPA; 20:5n-3) and the saturated fatty acid (16:0) constituted predominant fatty acids. In Temoralongicornis andEurytemora sp. total lipid content reported between $7 \%$ and $14 \%$ of the dry weight of which DHA accounted 26- 42\%, EPA $15-24 \%$ and Palmitic acid (16:0) $8-12 \%$. Comparable lipid content of DHA, EPA and Palmiticacid ranging between $21 \%$ and $32.5 \%, 15-21 \%$ and $9-15 \%$ of total fatty acids, respectively is also reported from another calanoid copepod, Calanus finmarchicus. ${ }^{7}$ 
Table 2: Cultivation conditions and micro-algal diets for Copepod culture

\begin{tabular}{|c|c|c|c|c|c|}
\hline \multirow[t]{2}{*}{ Name of the copepods } & \multicolumn{4}{|c|}{ Cultivation conditions } & \multirow[t]{2}{*}{ Reference } \\
\hline & $\begin{array}{l}\text { Temperature } \\
\text { (ㅇ) }\end{array}$ & $\begin{array}{l}\text { Salinity } \\
\text { (PPT) }\end{array}$ & $\begin{array}{l}\text { Photoperiod } \\
\text { (Light: Dark) }\end{array}$ & $\begin{array}{l}\text { Food diet } \\
\text { (Micro-algae) }\end{array}$ & \\
\hline Parvocalanuscrassirostris & $260 \mathrm{C}$ & 36 PPT & $16: 8 \mathrm{hrs}$ & $\begin{array}{l}\text { Isochrysissp., } \\
\text { Chaetocerosmuelleri } \\
\text { Thalassiosiraweissflogii }\end{array}$ & 43 \\
\hline Parvocalanuscrassirostris & $260 \mathrm{C}$ & 36 РPТ & $16: 8 \mathrm{hrs}$ & Isochrysissp. & 44 \\
\hline Oithonadavisae & $200 \mathrm{C}$ & 36 PPТ & 12:12 hrs & $\begin{array}{l}\text { Oxyrrhis marina } \\
\text { Rhodomonas salina }\end{array}$ & 45 \\
\hline $\begin{array}{l}\text { Acartiatonsa, Pseudocalanuslon- } \\
\text { gatus, Temoralongicornis }\end{array}$ & $150 \mathrm{C}$ & 35 PPT & $24 \mathrm{hrs}^{* *}$ & Skeletonemamarinoi & 46 \\
\hline $\begin{array}{l}\text { Macrosetella gracilis, Pseudodi- } \\
\text { aptomus sp. } \\
\text { Oithonarigida }\end{array}$ & $26-300 \mathrm{C}$ & 28-34 PPT & 12:12 hrs & Chlorella marina & 47 \\
\hline Pseudocyclopsumbraticus & $240 \mathrm{C}$ & $35 \mathrm{PPT}$ & $24 \mathrm{hrs}^{* *}$ & $\begin{array}{l}\text { Chaetomorphalinum } \\
\text { Tetraselmissuecica } \\
\text { Pavlovalutheri } \\
\text { Isochrysisgalbana }\end{array}$ & 48 \\
\hline Acartiatonsa & $260 \mathrm{C}$ & 35 PPT & 12:12 hrs & $\begin{array}{l}\text { Chaetocerosmuelleri } \\
\text { Isochrysisgalbana, } \\
\text { Nannochloropsis oculata. }\end{array}$ & 49 \\
\hline PseudocyclopsXiphophorus & $240 \mathrm{C}$ & 35 PPT & $24 \mathrm{hrs}^{* *}$ & $\begin{array}{l}\text { Skeletonemamarinoi } \\
\text { Tetraselmissuecica } \\
\text { Pavlovalutheri } \\
\text { Isochrysisgalbana }\end{array}$ & 50 \\
\hline Acartiatonsa, Acartia clause & $180 \mathrm{C}$ & 2-33 PPT & 12:12 hrs & Thalassiosiraweissflogii & 51 \\
\hline Acartiasinjiensis & $300 \mathrm{C}$ & 33 PРТ & 12:12 hrs & $\begin{array}{l}\text { Tetraselmischuii } \\
\text { Isochrysissp. }\end{array}$ & 52 \\
\hline Bestiolinasimilis & $260 \mathrm{C}$ & зо РPТ & 12:12 hrs & $\begin{array}{l}\text { Isochrysissp. } \\
\text { Pavlova salina } \\
\text { Tetraselmischuii } \\
\text { Chaetocerosmuelleri }\end{array}$ & 53 \\
\hline Bestiolinasimilis & $260 \mathrm{C}$ & 3оРPT & 12:12 hrs & $\begin{array}{l}\text { Isochrysissp., } \\
\text { Pavlova 5o } \\
\text { Tetraselmischuii } \\
\text { Chaetocerosmuelleri }\end{array}$ & 54 \\
\hline $\begin{array}{l}\text { Temorastylifera and } \\
\text { Centropagestypicus }\end{array}$ & $200 \mathrm{C}$ & зо РPT & 12:12 hrs & $\begin{array}{l}\text { Isochrysisgalbana } \\
\text { Prorocentrum minimum }\end{array}$ & 55 \\
\hline Temorastylifera & $200 \mathrm{C}$ & 3о РPT & 12:12 hrs & $\begin{array}{l}\text { Thalassiosirarotula } \\
\text { Skeletonemamarinoi } \\
\text { Prorocentrum minimum }\end{array}$ & 56 \\
\hline Eurytemoraaffinis & $150 \mathrm{C}$ & ${ }_{15} \mathrm{PPT}$ & 12:12 hrs & $\begin{array}{l}\text { Rhodomonas marina } \\
\text { Isochrysisgalbana }\end{array}$ & 57 \\
\hline Acartiatonsa & $170 \mathrm{C}$ & 34 PPT & $24 \mathrm{hrs}^{* *}$ & Rhodomonas salina & 58 \\
\hline Acartiatonsa & $17.60 \mathrm{C}$ & $34 \mathrm{PPT}$ & $24 \mathrm{hrs}^{* *}$ & Rhodomonas salina & 59 \\
\hline $\begin{array}{l}\text { Macrosetella gracilis } \\
\text { Pseudodiaptomus sp. } \\
\text { Oithonarigida }\end{array}$ & $26-30$ o $C$ & 28-34 PPT & 12:12 hrs & Chlorella marina & 60 \\
\hline Nitokraaffinis & $28-320 \mathrm{C}$ & 30-34 PPT & 12:12 hrs & $\begin{array}{l}\text { Isochrysisgalbana } \\
\text { Nannochloropsis salina } \\
\text { Chlorella marina }\end{array}$ & 61 \\
\hline
\end{tabular}


Table 2: (Continued)

\begin{tabular}{|c|c|c|c|c|c|}
\hline \multirow[t]{2}{*}{ Name of the copepods } & \multicolumn{4}{|c|}{ Cultivation conditions } & \multirow[t]{2}{*}{ Reference } \\
\hline & $\begin{array}{l}\text { Temperature } \\
\left({ }^{\circ} \mathrm{C}\right)\end{array}$ & $\begin{array}{l}\text { Salinity } \\
\text { (PPT) }\end{array}$ & $\begin{array}{l}\text { Photoperiod } \\
\text { (Light: Dark) }\end{array}$ & $\begin{array}{l}\text { Food diet } \\
\text { (Micro-algae) }\end{array}$ & \\
\hline Temorastylifera & $200 \mathrm{C}$ & 35 PPT & 12:12 hrs & $\begin{array}{l}\text { Pseudonitzschiadelicatissima } \\
\text { Skeletonemamarinoi } \\
\text { Prorocentrum minimum }\end{array}$ & 62 \\
\hline Parvocalanuscrassirostris & $260 \mathrm{C}$ & 36РPТ & $16: 8 \mathrm{hrs}$ & $\begin{array}{l}\text { Isochrysissp. } \\
\text { Chaetocerosmuelleri }\end{array}$ & 63 \\
\hline Macrosetella gracilis & $26-300 \mathrm{C}$ & 28-32PPT & 12:12 hrs & $\begin{array}{l}\text { Chlorella marina } \\
\text { DunaliellaSp. } \\
\text { Isochegrusisgalbana } \\
\text { Nannochloropsis Sp. }\end{array}$ & 64 \\
\hline Paracalanusparvus & $26-300 \mathrm{C}$ & 28-32 PPT & 12:12 hrs & $\begin{array}{l}\text { Chlorella marina } \\
\text { Dunaliella Sp., } \\
\text { Isochrysisgalbana } \\
\text { Nannochloropsis Sp., } \\
\text { Tetrasilmis Sp. } \\
\text { Skeletonemacostatum }\end{array}$ & 65 \\
\hline Pseudodiaptomus annandalei & $24.60 \mathrm{C}$ & 30 РPТ & $24 \mathrm{hrs}^{* *}$ & Isochrysisgalbana & 66 \\
\hline Acartia clause & $25-260 \mathrm{C}$ & $13-85$ PPT & 12:12 hrs & $\begin{array}{l}\text { Isochrysisgalbana } \\
\text { Chaetoceroscalcitrans }\end{array}$ & 67 \\
\hline Acartiatonsa & $200 \mathrm{C}$ & 30 РPТ & $16: 8 \mathrm{hrs}$ & Thalassiosiraweissflogii & 68 \\
\hline Acartia clause & $180 \mathrm{C}$ & 32 PPT & $24 \mathrm{hrs}^{* *}$ & $\begin{array}{l}\text { Thalassiosiraweissflogii } \\
\text { RhodomonasSp. }\end{array}$ & 69 \\
\hline $\begin{array}{l}\text { Centropagestypicus } \\
\text { Temoralongicornis }\end{array}$ & $14.70 \mathrm{C}$ & $35 \mathrm{PPT}$ & $24 \mathrm{hrs}^{* *}$ & Oxyrrhis marina & 70 \\
\hline Acartiasinjiensis & $280 \mathrm{C}$ & $34 \mathrm{PPT}$ & 12:12 hrs & $\begin{array}{l}\text { Nannochloropsis Sp. } \\
\text { Rhodomonasmaculata } \\
\text { Isochrysis Sp. } \\
\text { Tetraselmischuii }\end{array}$ & 71 \\
\hline Pseudodiaptomus euryhalinus & $270 \mathrm{C}$ & $35 \mathrm{PPT}$ & 12:12 hrs & $\begin{array}{l}\text { Chaetocerosmuelleri } \\
\text { Nannochloropsis oculata } \\
\text { Isochrysisgalbana } \\
\text { Tetraselmissuecica }\end{array}$ & 72 \\
\hline Acartia clause & $320 \mathrm{C}$ & 34 PPT & 12:12 hrs & $\begin{array}{l}\text { Isochrysisgalbana } \\
\text { Chaetocerosaffinis } \\
\text { Chlorella marina }\end{array}$ & 73 \\
\hline Temorastylifera & $200 \mathrm{C}$ & 34 PPT & 12:12 hrs & Prorocentrum minimum & 74 \\
\hline Oithonarigida & $26-300 \mathrm{C}$ & 28-34 PPT & 12:12 hrs & $\begin{array}{l}\text { Coscinodiscuscentralis } \\
\text { Skeletonemacostatum } \\
\text { Chlorella marina } \\
\text { Chaetocerosaffinis }\end{array}$ & 75 \\
\hline Oithonarigida & $280 \mathrm{C}$ & 30 PPT & $16: 8 \mathrm{hrs}$ & $\begin{array}{l}\text { Chlorella marina } \\
\text { Isochrysisgalbana } \\
\text { Dunaliella salina } \\
\text { Tetraselmissuecica } \\
\text { Nannochloropsis salina }\end{array}$ & 76 \\
\hline
\end{tabular}


Table 2: (Continued)

\begin{tabular}{|c|c|c|c|c|c|}
\hline \multirow[t]{2}{*}{ Name of the copepods } & \multicolumn{4}{|c|}{ Cultivation conditions } & \multirow[t]{2}{*}{ Reference } \\
\hline & $\begin{array}{l}\text { Temperature } \\
\left({ }^{\circ} \mathrm{C}\right)\end{array}$ & $\begin{array}{l}\text { Salinity } \\
\text { (PPT) }\end{array}$ & $\begin{array}{l}\text { Photoperiod } \\
\text { (Light: Dark) }\end{array}$ & $\begin{array}{l}\text { Food diet } \\
\text { (Micro-algae) }\end{array}$ & \\
\hline Nannocalanus minor & $26-300 \mathrm{C}$ & 28-32 PPT & 12:12 hrs & $\begin{array}{l}\text { Chlorella marina } \\
\text { Dunaliella salina, } \\
\text { Isochrysisgalbana, } \\
\text { Nannochloropsis Sp., } \\
\text { Coscinodiscuscentralis, } \\
\text { Chaetocerosaffinis } \\
\text { Skeletonemacostatum }\end{array}$ & 77 \\
\hline Acartia spp. & $280 \mathrm{C}$ & 30-34 PPT & 12:12 hrs & $\begin{array}{l}\text { RhodomonasSp., } \\
\text { TetraselmisSp. } \\
\text { IsochrysisSp. }\end{array}$ & 78 \\
\hline Acartiatonsa & $200 \mathrm{C}$ & 30 РPТ & 12:12 hrs & $\begin{array}{l}\text { Thalassiosiraweissflogii } \\
\text { Chaetocerosmuelleri } \\
\text { Isochrysisgalbana }\end{array}$ & 79 \\
\hline Parvocalanuscrassirostris & $260 \mathrm{C}$ & 36 РPТ & $16: 8 \mathrm{hrs}$ & Chaetocerosmuelleri & 80 \\
\hline Acartiatonsa & $180 \mathrm{C}$ & $34 \mathrm{PPT}$ & 12:12 hrs & $\begin{array}{l}\text { Rhodomonasbaltica } \\
\text { Thalassiosiraweissflogii } \\
\text { Rhodomonasbaltica } \\
\text { Dunaliellatertiolecta }\end{array}$ & 81 \\
\hline Acartiatonsa & $200 \mathrm{C}$ & зо РPT & 14:10 hrs & $\begin{array}{l}\text { Isochrysisgalbana } \\
\text { Rhodomonasbaltica } \\
\text { Rhinomonas reticulata }\end{array}$ & 82 \\
\hline Acartiatonsa & $18-190 \mathrm{C}$ & 30 PPT & $24 \mathrm{hrs}^{* *}$ & Rhodomonas salina & 83 \\
\hline Tisbe sp., & $18-38$ o C & $18-38$ PPT & 12:12 hrs & $\begin{array}{l}\text { Chlorella marina } \\
\text { Dunaliella salina } \\
\text { Isochrysisgalbana } \\
\text { Nannochloropsis salina } \\
\text { Tetraselmissuecica }\end{array}$ & 84 \\
\hline Parastenhelia sp. & $280 \mathrm{C}$ & 32 PPT & 12:12 hrs & Isochrysisgalbana & 85 \\
\hline Nannocalanus minor & $280 \mathrm{C}$ & $32 \mathrm{PPT}$ & 12:12 hrs & $\begin{array}{l}\text { Chlorella marina } \\
\text { Dunaliellasp., } \\
\text { Isochrysisgalbana } \\
\text { Nannochloropsis sp., } \\
\text { Coscinodiscuscentralis } \\
\text { Chaetocerosaffinis } \\
\text { Skeletonemacostatum }\end{array}$ & 86 \\
\hline Tigriopus japonicas & $250 \mathrm{C}$ & 34 PPT & 12:12 hrs & Tetraselmistetrathele & 87 \\
\hline Cyclopina sp. & $270 \mathrm{C}$ & 26 PPТ & 12:12 hrs & Tetraselmissuecica & 88 \\
\hline Pseudodiaptomus hessei & $220 \mathrm{C}$ & $27 \mathrm{PPT}$ & 12:12 hrs & $\begin{array}{l}\text { Isochrysisgalbana } \\
\text { Tetraselmissuecica }\end{array}$ & 89 \\
\hline Nitocraaffinis & $28-300 \mathrm{C}$ & зо РPТ & 12:12 hrs & $\begin{array}{l}\text { Chlorella marina } \\
\text { Isochrysisgalbana } \\
\text { Dunaliella salina } \\
\text { Nannochloropsis oculata } \\
\text { Tetraselmissuecica }\end{array}$ & 90 \\
\hline Oithonarigida & $16-360 \mathrm{C}$ & 10-40 PPT & 12:12 hrs & $\begin{array}{l}\text { Ichlorella marina } \\
\text { Isochrysisgalbana } \\
\text { Dunaliella salina } \\
\text { Tetraselmissuecica } \\
\text { Nannochloropsis salina }\end{array}$ & 6 \\
\hline
\end{tabular}

${ }^{*}$ PPT - Parts Per Thousand; **24 hrs in a dark place 
The calanoid copepods especially Acartiatonsa are a rich source of essential highly unsaturated fatty acids (HUFAs) such as docosahexaenoic acid and eicosapentaenoic acid. ${ }^{32}$ The fatty acid composition of Acartiatonsacontain high amount of monounsaturated fatty acid $\left(411 \mathrm{mg} \mathrm{g}^{-1}\right)$, and polyunsaturated fatty acids $\left(360 \mathrm{mg} \mathrm{g}^{-1}\right)$. A large amount of DHA and EPA (170 and $96 \mathrm{mg} \mathrm{g}^{-1}$, respectively) reported in this species. ${ }^{120}$ Several marine copepods have a high content of both docosahexaenoic acid (DHA) and eicosapentaenoic acid (EPA) ( $60 \%$ of total fatty acids). ${ }^{7}$ Also, the copepods are natural sources of the antioxidant, astaxanthin and vitamins $\mathrm{C}$ and E. ${ }^{32}$ The powerful antioxidants found in copepods can protect the HUFA's against peroxidation and are also considered beneficial to the health of fish larvae. ${ }^{69}$ An exogenous supply of free amino acids (FAA) is necessary to support growth and survival in first feeding finfish larvae. ${ }^{121}$ Copepods contain higher levels of free amino acids when compared to rotifers and Artemia nauplii. ${ }^{32}$ Copepods generally contain more vitamins and trace minerals than traditional live feeds. ${ }^{122}$ Copepods are rich in vitamin $\mathrm{E}$ and ascorbic acid, suggesting a high antioxidative capacity and making them particularly suitable for larvae with potential for high growth rates. ${ }^{32}$ Furthermore, copepods are rich in pigment content, particularly astaxanthin, which may be an important source of retinoids for larval fish. ${ }^{32} \mathrm{~A}$ copepod diet has been reported to promote correct pigmentation in Atlantic halibut larvae, with $55 \%$ of the copepod fed larvae exhibiting correct pigmentation of the ocular and blindsides as compared to only $13 \%$ in those fed Artemia nauplii. ${ }^{123}$ Thus it is generally accepted that many copepods are the valuable nutrient source of live feed for marine larval finfish rearing. With varying food and feeding habits and reproductive strategies among even in closely related copepod species it necessary to venture in to establish their mass production protocols. Further such research is needed to identify the copepod species which matches nutritionally and in size spectrum with the requirement of specific marine finfish larval rearing.

\section{CONCLUSION}

This review reveals the importance of micro-algal for the culture of copepods, nevertheless, such studies are mostly of small scale level and to reach cost-effective commercialscale production, attempts should have made to enumerating new species for mass production. They have to be mass cultured with the knowledge of their reproductive potentials and reproductive strategies. Considering copepod suitability for successful rearing of many finfish larvae further research is urgently needed to assess the culture potential of more candidate copepods as prey for the rearing of early stages of marine finfish larvae which in turn might greatly benefit the mariculture industry.

\section{ACKNOWLEDGEMENT}

The authors express their gratitude to the Management of AMET University for providing research facilities to carry out this work. The authors are thankful to the Department of Biotechnology, Govt. of India for funding a project (BT/ PR30019/AAQ/3/929/2018) for Copepod culture studies. The authors acknowledge the immense help received from the scholars whose articles are cited and included in references to this manuscript. The authors are also grateful to authors/editors/publishers of all those articles, journals and books from where the literature for this article has been reviewed and discussed.

\section{Author Contributions}

All the authors contributed equally for this reviewwork.

\section{Conflict of interest}

The authors have no conflict of interest.

\section{REFERENCES}

1. Das P, Mandal SC, Bhagabati SK, Akhtar MS, Singh SK. Important live food organisms and their role in aquaculture. Front Mar Sci 2012;5(4):69-86.

2. Southgate PC. Hatchery and Larval Foods. In Aquaculture: Farming Aquatic Animals and Plants. Wiley-Blackwell Chichester 2019;12:183-201.

3. Altaff K, Janakiraman A. Effect of temperature on mass culture of three species of zooplankton, Brachionus plicatilis, Ceriodaphnia reticulate and Apocyclopsdengizicus. Int J Fish Aquat Stud 2015; 2(4): 49-53.

4. Wu RA, Ding Q, Yin L, Chi X, Sun N, He R, Li Z. Comparison of the nutritional value of mysore thorn borer (Anoplophorachinensis) and mealworm larva (Tenebriomolitor): Amino acid, fatty acid, and element profiles. Food Chem 2020; 126818.

5. Nielsen R, Nielsen M, Abate TG, Hansen BW, Jepsen PM, Nielsen SL, Buchmann K. The importance of live feed trapsfarming marine fish species. Aquac Res 2017;48(6): 26232641.

6. Santhanam P, Jeyaraj N, Jothiraj K, Ananth S, Kumar SD, Pachiappan P. Assessing the Efficacy of Marine Copepods as an Alternative First Feed for Larval Production of Tiger Shrimp Penaeusmonodon. Basic and Applied Zooplankton Biology: Springer Nature; 2019. p.293-303.

7. Evjemo JO, Olsen Y. Lipid and fatty acid content in cultivated live feed organisms compared to marine copepods. Hydrobiologia 1997; 358:159-162.

8. Takeuchi T. A review of feed development or early life stages of marine finfish in Japan. Aquaculture 2001; 200: 203-222.

9. Lee S, O’Bryen PJ, Marcus NH, Copepods in Aquaculture. Blackwell Publishing,2005; 269.

10. Nandakumar R, Santhanam PA. Study on Assessing the Feeding, Survival, Fecundity, and Postembryonic Development of Zooplankton Nitocraaffinis (Copepoda: Harpacticoida). Basic and Applied Zooplankton Biology: Springer Nature; 2019. p. 257-276. 
11. Lubzens E, Zmora O, Barr Y. Biotechnology and aquaculture of rotifers. Hydrobiologia 2001;446:337-353.

12. Conceicão C, Yúfera M, Makridis P, Morais S, Dinis MT. Live feeds for early stages of fish rearing. Aquac Res 2010;41:613640.

13. Altaff K, Chandran MR. Sex-related biochemical investigation of the diaptomid, Heliodiaptomus viduus Gurney (Crustacea: Copepoda). Proc Natl Acad Sci India Sect B Biol Sci 1989; 98(3):175-179.

14. Aman S, Altaff K. Biochemical profile of Heliodiaptomus viduus, Sinodiaptomus (Rhinediaptomus) indicus and Mesocyclops aspericornis and their dietary evaluation for postlarvae of Macrobrachium rosenbergii. Zool Stud 2004; 43(2): 267275.

15. Begum BD, Dharani G, Altaff K. Effect of temperature on the egg production and hatching success of Sinodiaptomus (Rhinediaptomus) Indicus (Calanoida: Copepoda). African J Basic Appl Sci 2012;4(6):216-220.

16. Anandan P, Krishnamurthy R, Altaff K. Studies on different stages of post embryonic development of cyclopoid copepod Apocyclopsdengizicus. Int J Curr Microbiol App Sci 2013;2(2): 20-27.

17. Sampey A, McKinnon A, Meekan G, McCormick M, Glimpse into guts: overview of the feeding of larvae of tropical shore fishes. Mar Ecol Prog Ser 2007;339:243-257.

18. DharaniG,AltaffK.Ultrastructure ofsubitaneousanddiapausing eggs of planktonic copepod Sinodiaptomus(Rhinediaptomus) indicus. Curr Sci 2004;87(1):109-112.

19. Altaff K. Breeding biology of freshwater Copepoda Heliodiaptomus viduus (Gurney) and its prospects as live food organisms. Pak J Sci Ind Res 2003;46(3):180-197.

20. Toledo J, Golez MS, Doi M, Ohno A. Use of copepod nauplii during early feeding stage of grouper Eponepheluscoioides. Fish Sci 1999;65:390-397.

21. Garcia AS, Parrish C, Brown J. Growth and lipid composition of Atlantic cod (Gadusmorhua) larvae in response to differently enriched Artemia fransiscana. Fish Physiol Biochem 2008;34:77-94.

22. Koedijk R, Folkvord A, Foss A, Pittman K, Stefansson SO, Handeland S, Imsland K. The influence of first-feeding diet on the Atlantic cod Gadusmorhua phenotype: survival, development and long term consequences for growth. J Fish Biol 2010;77:1-19.

23. Lindley LC, Phelps P, Davis DA, Cummins KA. Salinity acclimation and free amino acid enrichment of copepod nauplii for first-feeding of larval marine fish. Aquaculture 2011; 318 : 402-406.

24. Browne RA, McDonald GH, Biogeography of the brine shrimp, Artemia: distribution of parthenogenetic and sexual populations. J Biogeogr 1982;9:331-338.

25. Luizi FS, Gara B, Shields R, Bromage NR, Further description of the development of the digestive organs in Atlantic halibut (Hippoglossushippoglossus) larvae with note on differential absorption of copepod and Artemia prey.Aquaculture 1999;176:101-116.

26. Van Stappen G, Zoogeography. In: Abatzopoulos TH, Beardmore J, Clegg JS, Sorgeloos P (Eds.), Artemia: Basic and Applied Biology. Kluwer Academic Publishers, Dordrecht, The Netherlands 2002; p. 171-224.

27. Bell JG, McEvoy LA, Estevez A, Shields RJ, Sargent JR. Optimizing lipid nutrition in first feeding flatfish larvae. Aquaculture 2003;227:211-220.

28. Liu G, Xu D. Effects of calanoid copepod Schmackeriapoplesia as live food on the growth, survival and fatty acid composi- tion of larvae and juvenile of Japanese Flounder, Paralichtysolivaceus. J Ocean Univ China 2009;8:359-365.

29. Navarro JC, Batty RS, Bell MV, Sargent JR. Effects of two Artemia diets with different contents of polyunsaturated fatty acids on the lipid composition of larva of Atlantic herring (clupeaharengus). J Fish Biol 1993;43:503-515.

30. Duggan IC, Green JD, Shiel RJ. Distribution of rotifer assemblages in North Island, New Zealand, lakes: relationships to environmental and historical factors. Freshwater biology 2002;47:195-206.

31. Yoshida T, Urabe J, Elser JJ. Assessment of 'top-down' and 'bottom-up' forces as determinants of rotifer distribution among lakes in Ontario, Canada. Ecol Res 2003;18:639-650.

32. Van der Meeren T. Analysis of biochemical components in copepods for evaluation of feed quality for juvenile production of marine fish. Aquaculture 2003;39.

33. Luizi FS, Gara B, Shields R, Bromage NR, Further description of the development of the digestive organs in Atlantic halibut (Hippoglossushippoglossus) larvae with note on differential absorption of copepod and Artemia prey. Aquaculture 1999; 176: 101-116.

34. Bell JG, McEvoy LA, Estevez A, Shields RJ, Sargent JR. Optimizing lipid nutrition in first feeding flatfish larvae. Aquaculture 2003; 227: 211-220.

35. Buskey EJ, Coulter C, Strom S. Locomotory patterns of microzooplankton: potenti potential effects on food selectivity of larval fish. Bull Mar Sci 1993; 53: 29-43.

36. Dahms U. Dormancy in the Copepoda-an overview. Hydrobiologia 1995; 306: 199-211.

37. Holm M, Kiørboe T, Brun P, Licandro P, Almeda R, Hansen B W. Resting eggs in free living marine and estuarine copepods. J Plankton Res2018; 40: 2-15.

38. Pan Y, Souissi A, Sadovskaya I, Hwang J S, and Souissi S. Egg hatching rate and fatty acid composition of Acartiabilobata (Calanoida, Copepoda) across cold storage durations. Aquac Res 2019; 50: 483-489.

39. Puello-Cruz C, Mezo-Villalobos S, González-Rodríguez B, Voltolina D. Culture of the calanoid copepod Pseudodiaptomus euryhalinus (Johnson 1939) with different microalgal diets. Aquaculture 2009; 290 (4): 317-319.

40. Ohs CL, Chang KL, Grabe SW, DiMaggio MA, Stenn E. Evaluation of dietary microalgae for culture of the calanoid copepod Pseudodiaptomus pelagicus. Aquaculture 2010; 307 (4): 225-232.

41. Jepsen PM, Thoisen CV, Cabaret T, Gallemí A, Nielsen SL, Hansen BW. Effects of salinity, commercial salts, and water type on cultivation of the cryptophyte microalgae Rhodomonas salina and the calanoid copepod Acartiatonsa. J World Aquac Soc 2019; 50(1):104-118.

42. Ayadi FY, Rosentrater KA, \&Muthukumarappan K. Alternative protein sources for aquaculture feeds. J Aqua Feed Sci Nut 2012; 4(1), 1-26.

43. Alajmi F, Zeng C, Jerry DR. Domestication as a novel approach for improving the cultivation of calanoid copepods: a case study with Parvocalanuscrassirostris. PloS One 2015; 10 (7):1-16.

44. Alajmi F, Zeng, C. Evaluation of microalgal diets for the intensive cultivation of the tropical calanoid copepod, Parvocalanuscrassirostris. Aquac Res 2015;46(5):1025-1038.

45. Almeda R, Calbet A, Alcaraz M, Yebra L, Saiz, E. Effects of temperature and food concentration on the survival, development and growth rates of naupliar stages of Oithonadavisae (Copepoda, Cyclopoida). Mar Ecol 2010; 410: 97-109.

46. Amin RM, Koski M, Båmstedt U, Vidoudez C. Strain-related physiological and behavioral effects of Skeletonemamari- 
noi on three common planktonic copepods. Mar Biol 2011; 158(9): 1965-1980.

47. Ananthi P, Santhanam P, Nandakumar R, Ananth S, Jothiraj K, Kumar SD, et al. Production and utilization of marine copepods as live feed for larval rearing of tiger shrimp $P e$ naeusmonodon with special emphasis on astaxanthin enhancement. Ind J Nat Sci 2011; 0997.

48. Brugnano C, Guglielmo L, Zagami G. Food type effects on reproduction of hyperbenthic calanoid species Pseudocyclopsxiphophorus Wells, 1967, under laboratory conditions. J Chem Ecol 2008; 24(S1): 111-117.

49. Barroso MV, De Carvalho, Antoniassi R, Cerqueira V. Use of the copepod Acartiatonsa as the first live food for larvae of the fat snook Centropomusparallelus. Aquaculture 2013; 388: 153-158.

50. Brugnano C, Guglielmo L, Zagami G. Food type effects on reproduction of hyperbenthic calanoid species Pseudocyclopsxiphophorus Wells, 1967, under laboratory conditions. J Chem Ecol 2008; 24(S1): 111-117.

51. Calliari D, Andersen CM, Thor P, Gorokhova E, Tiselius P. Salinity modulates the energy balance and reproductive success of co-occurring copepods Acartiatonsa and A. clausi in different ways. Mar Ecol 2006;312:177-188.

52. Camus T, Zeng C. Effects of photoperiod on egg production and hatching success, naupliar and copepodite development, adult sex ratio and life expectancy of the tropical calanoid copepod Acartiasinjiensis. Aquaculture 2008;280(4):220-226.

53. Camus $\mathrm{T}$, Zeng C. Roles of microalgae on total egg production over female lifespan and egg incubation time, naupliar and copepodite survival, sex ratio and female life expectancy of the copepod Bestiolinasimilis. Aquac Res 2010;41(11):17171726.

54. Camus T, Zeng C, McKinnon AD. Egg production, egg hatching success and population increase of the tropical paracalanid copepod, Bestiolinasimilis (Calanoida: Paracalanidae) fed different microalgal diets. Aquaculture 2009; 297(4): 169-175.

55. Carotenuto Y, Ianora A, Di Pinto M, Sarno D, Miralto A. Annual cycle of early developmental stage survival and recruitment in the copepods Temorastylifera and Centropagestypicus. Mar Ecol 2006;314:227-238.

56. Carotenuto Y, Ianora A, Miralto A. Maternal and neonate diatom diets impair development and sex differentiation in the copepod Temorastylifera. J Exp Mar Biol Ecol 2011; 396(2): 99-107.

57. Devreker D, Souissi S, Seuront L. Effects of chlorophyll concentration and temperature variation on the reproduction and survival of Temoralongicornis (Copepoda, Calanoida) in the Eastern English Channel. J Exp Mar Biol Ecol 2005; 318(2): 145-162.

58. Drillet G, Rais M, Novac A, Jepsen PM, Mahjoub MS, Hansen BW. Total egg harvest by the calanoid copepod Acartiatonsa (Dana) in intensive culture-effects of high stocking densities on daily egg harvest and egg quality. Aquac Res 2015; 46 (12): 3028-3039.

59. Drillet G, Goetze E, Jepsen M, Højgaard JK, Hansen B. Strainspecific vital rates in four Acartiatonsa cultures, I: strain origin, genetic differentiation and egg survivorship. Aquaculture 2008; 280 (4): 109-116.

60. Ananthi P, Santhanam P, Nandakumar R, Ananth S, Jothiraj K, Kumar SD, Jayalakshmi T. Production and utilization of marine copepods as live feed for larval rearing of tiger shrimp Penaeusmonodon with special emphasis on astaxanthin enhancement. Ind J Nat Sci 2011; 0997.

61. Rajthilak C, Santhanam P, Anusuya A, Pazhanimuthu A, Ramkumar R, Jeyaraj N, et al. Laboratory culture and pop- ulation growth of brackish water harpacticoid copepod, Nitokraaffinis(Gurney, 1927) under different temperatures, salinities and diets. World J Fish Marine Sci 2014; 6(1): 72-8.

62. Ianora A, Romano G, Carotenuto Y, Esposito F, Roncalli V, Buttino I, et al. Impact of the diatom oxylipin 15S-HEPE on the reproductive success of the copepod Temorastylifera. Hydrobiologia 2011; 666(1): 265-275.

63. Alajmi F, Zeng, C. Evaluation of microalgal diets for the intensive cultivation of the tropical calanoid copepod, Parvocalanuscrassirostris. Aquac Res 2015;46(5):1025-1038.

64. Jeyaraj N, Santhanam P, Raju P, Ananth S, Jothiraj K. Alternative methods for marine harpacticoid copepod, Macrosetella gracilis production in marine fish larviculture. Int J Zool Res 2014;10(1):1-8.

65. Jeyaraj N, Santhanam P. Influence of algal diet on population density, egg production and hatching succession of the calanoid copepod, Paracalanusparvus (Claus, 1863). J Algal Biomass Utln 2013;4(1):1-8.

66. Kaviyarasan M, Santhanam PA. Technique on the Culture and Preservation of Marine Copepod Eggs. Basic Appl Zooplankton Biol 2019;34:197-208.

67. Abolghasem EF, Majid S, Naser A, Hossein O, Shima MA. Laboratory culture of the Caspian Sea calanoid copepod Acartiaclausi(Giesbrecht, 1889) at different salinity levels. World J Fish Marine Sci 2011;3(6): 590-599.

68. Lauer MM, Bianchini A. Chronic copper toxicity in the estuarine copepod Acartiatonsa at different salinities. J Environ Chem Ecotoxicol 2010; 29(10):2297-2303.

69. Leandro SM, Queiroga H, Rodríguez-Graña L, Tiselius P. Temperature-dependent development and somatic growth in two allopatric populations of Acartiaclausi (Copepoda: Calanoida). Mar Ecol 2006;322:189-197.

70. McConville K, Halsband C, Fileman ES, Somerfield PJ, Findlay HS, Spicer JI. Effects of elevated $\mathrm{CO}_{2}$ on the reproduction of two calanoid copepods. Mar Pollut Bull 2013; 73(2): 428434.

71. Milione M, Zeng C. The effects of algal diets on population growth and egg hatching success of the tropical calanoid copepod, Acartiasinjiensis. Aquaculture 2007; 273(4): 656-664.

72. Puello-Cruz C, Mezo-Villalobos S, González-Rodríguez B, Voltolina D. Culture of the calanoid copepod Pseudodiaptomus euryhalinus (Johnson 1939) with different microalgal diets. Aquaculture 2009;290(4):317-319.

73. Rajkumar M. Suitability of the copepod, Acartiaclausi as a live feed for Seabass larvae (Latescalcarifer Bloch): Compared to traditional live-food organisms with special emphasis on the nutritional value. Aquaculture 2006; 261(2), 649-658.

74. Kâ S, Carotenuto Y, Romano G, Hwang JS, Buttino I, Ianora A. Impact of the diatom-derived polyunsaturated aldehyde 2-trans, 4-trans decadienal on the feeding, survivorship and reproductive success of the calanoid copepod Temorastylifera. Mar Environ Res 2014; 93: 31-37.

75. Santhanam P, Perumal P. Effect of temperature, salinity and algal food concentration on population density, growth and survival of marine copepod Oithonarigida Giesbrecht. Indian J Mar Sci 2012; 41(4), 369-376.

76. Santhanam P, Ananth S, Kumar SD, Sasirekha R, Premkumar C, Jeyanthi S, Devi AS. An Intensive Culture Techniques of Marine Copepod Oithonarigida (Dioithonarigida) Giesbrecht. Basic Appl Zooplankton Biol 2019;36:367-394.

77. Ananth S, Santhanam P. Intensive Culture, Biochemical Composition Analysis, and Use of Zooplankton Tisbe sp.(Copepoda: Harpacticoida) as an Alternative Live Feed for Shrimp Larviculture. Basic Appl Zooplankton Biol 2019;36:329-362. 
78. Schipp GR, Bosmans JM, Marshall AJ. Method for hatchery culture of tropical calanoid copepods, Acartia spp. Aquaculture 1999; 174(2): 81-88.

79. Teixeira PF, Kaminski SM, Avila TR, Cardozo AP, Bersano JG, Bianchini A. Diet influence on egg production of the copepod Acartiatonsa (Dana, 1896). Anais da Academia Brasileira de Ciências 2010; 82(2): 333-339.

80. Alajmi F, Zeng, C. Evaluation of microalgal diets for the intensive cultivation of the tropical calanoid copepod, Parvocalanuscrassirostris. Aquac Res 2015;46(5):1025-1038.

81. Wendt I, Thor P. Influence of prey species and concentration on egg production efficiency and hatching success in Acartiatonsa Dana (Copepoda, Calanoida). Crustaceana 2015; 88(6): 675-687.

82. Zhang J, Ianora A, Wu C, Pellegrini D, Esposito F, Buttino I. How to increase productivity of the copepod Acartiatonsa (Dana): effects of population density and food concentration. Aquac Res 2015; 46(12): 2982-2990.

83. Drillet G, Iversen MH, Sørensen TF, Ramløv H, Lund T, Hansen BW. Effect of cold storage upon eggs of a calanoid copepod, Acartiatonsa(Dana) and their offspring. Aquaculture 2006; 254 (4): 714-729.

84. Kaviyarasan M, Santhanam P, Ananth S, Kumar SD, Rao GH, Jayakumar, Kandan, S. Mass production and biochemical composition of marine copepod Pseudodiaptomus Annandalei. Int J Appl Res 2019; 9(2): 41-51.

85. Jayalakshmi T, Santhanam PA Microcosm Study on the Impact of Acidification on Feeding, Survival, Nauplii Production Rate, Post-embryonic Development and Nutritional Composition of Marine Basic Appl Zooplankton Biol 2019;36:395-428.

86. Jothiraj K, Santhanam P. Optimisation of the Culture Conditions of Nannocalanus minor (Copepoda: Calanoida Basic Appl Zooplankton Biol 2019;36:225-246.

87. Kim HJ, Yamade T, Iwasaki K, Marcial HS, Hagiwara A. Phototactic behavior of the marine harpacticoid copepod Tigriopusjaponicus related to developmental stages under various light conditions. J Exp Mar BiolEcol 2019; 518: 151183.

88. Burbano MF, Torres GA, Prieto MJ, Gamboa JH, Chapman FA. Increased survival of larval spotted rose snapper Lutjanusguttatus (Steindachner, 1869) when fed with the copepod Cyclopina sp. and Artemia nauplii. Aquaculture 2020; 519: 734912.

89. Mzozo ZB, Matcher GF, Vine NG. Aspects of the feeding biology of the copepod Pseudodiaptomus hessei (Copepoda: Calanoida) under culture conditions. Aquac Res 2019; 50(4): 1329-1337.

90. Perumal S, Ananth S, Nandakumar R, Jayalakshmi T, Kaviyarasan M, Pachiappan P. Intensive indoor and outdoor pilot-scale culture of marine copepods. Aquaculture 2015; 33-42.

91. Coutteau P, Sorgeloos P. Manipulation of dietary lipids, fatty acids and vitamins in zooplankton cultures. Freshw Biol 1997; 38(3), 501-512.

92. Brown MR, Jeffrey SW, Volkman JK, Dunstan GA. Nutritional properties of microalgae for mariculture. Aquaculture 1997; 151(4): 315-331.

93. Wild KJ, Trautmann A, Katzenmeyer M, Steinga H, Posten C, Rodehutscord M. Chemical composition and nutritional characteristics for ruminants of the micro-algae Chlorella vulgaris obtained using different cultivation conditions. Algal Res 2019; 38: 101385.

94. Rosenberg JN, Oyler GA, Wilkinson L, Betenbaugh MJ. A green light for engineered algae: redirecting metabolism to fuel a biotechnology revolution. Curr Opin Biotechnol 2008; 19(5): 430-436.
95. Yen HW, Hu IC, Chen CY, Nagarajan D, Chang JS. Design of photobioreactors for algal cultivation. In Biofuels From Algae 2019; 225-256.

96. Enright CT, Newkirk GF, Craigie JS, Castell JD. Growth of juvenile Ostreaedulis L. fed ChaetoceroscalcitransSchütt of varied chemical composition. J Exp Mar Biol Ecol 1986; 96:15-26.

97. Thompson PA, Guo MX, Harrison PJ. The influence of irradiance on the biochemical composition of three phytoplankton species and their nutritional value for larvae of the Pacific oyster (Crassostreagigas). Mar Biol 1993;117:259-268.

98. Brown MR, Miller KA, The ascorbic acid content of eleven species of microalgae used in mariculture. J Appl Phycol 1992; 4: 205-215.

99. Ibbetts SM, Melanson RJ, Park KC, Banskota AH, Stefanova R, Janssen, M. Cultivation of microalgae, effect of light/dark cycles on biomass yield [PhD thesis]. Wageningen: Wageningen University 2002.

100. Parsons TR, Stephens K, Strickland J. On the chemical composition of eleven species of marine phytoplankters. Fish Res 1961;18:1001-1016.

101. Webb KL, Chu FE. Phytoplankton as a food source for bivalve larvae. In: G. D. Pruder, C. J. Langdon and D. E. Conklin (Editors), Proceedings of the Second International Conference on Aquaculture Nutrition: Biochemical and Physiological Approaches to Shellfish Nutrition, Louisiana State University, Baton Rouge 1983; 272-291.

102. Yebra L, Berdalet E, Almeda R, Pérez V, Calbet A, and Saiz E. Protein and nucleic acid metabolism as proxies for growth and fitness of Oithonadavisae (Copepoda, Cyclopoida) early developmental stages. J Exp Mar Biol Ecol 2011;406 (2):87-94.

103. Shah MR, Liang Y, Cheng JJ, Daroch M. Astaxanthin-producing green microalga Haematococcuspluvialis: from single cell to high value commercial products. Front Plant Sci 2016; 7:531.

104. Becker E. Micro-algae as a source of protein. Biotechnol Adv 2007; 25: 207-210.

105. Tibbetts SM, Milley JE, Lall SP. Chemical composition and nutritional properties of freshwater and marine microalgal biomass cultured in photobioreactors. J Appl Phycol 2015; 27:1109-1119.

106. Becker EW. Microalgae: biotechnology and microbiology. Cambridge University Press, Cambridge 1994; 293.

107. Shields RJ, Lupatsch I. Algae for aquaculture and animal feeds. J Anim Sci 2012; 21:23-37.

108. Becker EW. Microalgae: biotechnology and microbiology. Cambridge University Press, Cambridge 1994; 293.

109. Tibbetts SM, Milley JE, Lall SP. Apparent protein and energy digestibility of common and alternative feed ingredients by Atlantic cod, Gadusmorhua (Linnaeus, 1758). Aquaculture 2006; 261: 1314-1327.

110. Tibbetts SM, Whitney CG, MacPherson MJ, Bhatti S, Banskota AH, Stefanova R, et al. Biochemical characterization of microalgal biomass from freshwater species isolated in Alberta, Canada for animal feed applications. Algal Res 2015; 11: 435-447.

111. Shields RJ, Bell JG, Luizi FS, Gara B, Bromage NR, Sargent JR. Natural copepods are superior to enriched Artemia nauplii as feed for larvae (Hippoglossushippoglossus) in terms of survival, pigmentation and retinal morphology: relation to dietary essential fatty acids. J Nutr 1999; 129(6):1186-1194.

112. Vizcaíno A, López G, Sáez M, Jiménez J, Barros A, Hidalgo L, Camacho-Rodríguez J, Martínez T, Cerón-García M, Alarcón F. Effects of the microalga Scenedesmusalmeriensisas fish- 
meal alternative in diets for gilthead sea bream, Sparusaurata, juveniles. Aquaculture 2014; 431:34-43.

113. Kiron V, Phromkunthong W, Huntley M, Archibald I, Scheemaker GD. Marine microalgae from biorefinery as a potential feed protein source for Atlantic salmon, common carp and whiteleg shrimp. Aquac Nutr 2012; 18:521-531.

114. Tulli F, ChiniZittelli G, Giorgi G, Poli BM, Tibaldi E, Tredici MR. Effect of the inclusion of dried Tetraselmissuecicaon growth, feed utilization, and fillet composition of european sea bass juveniles fed organic diets. J Aquat Food Prod Technol 2012; 21:188-197.

115. Langdon CJ, Waldock MJ. The effect of algal and artificial diets on the growth and fatty acid composition of Crassostreagigas spat. J Mar Biol 1981; 61: 431-448.

116. Dunstan GA, Volkman JK, Barrett SM, Leroi JM, Jeffrey SW. Essential polyunsaturated fatty acids from fourteen species of diatom (Bacillariophyceae). Phytochemistry 1994; 35:155161.

117. Brown MR, Miller KA, The ascorbic acid content of eleven species of microalgae used in mariculture. J Appl Phycol 1992; 4: 205-215.
118. Anderson TR, Pond DW. Stoichiometric theory extended to micronutrients: comparison of the roles of essential fatty acids, carbon, and nitrogen in the nutrition of marine copepods. Limnol Oceanogr 2000; 45: 1162-1167.

119. Sun B, Fleeger JW. Sustained mass culture of Amphiascoidesatopus a marine harpacticoid copepod in a recirculating system. Aquaculture 1995; 136: 313-321.

120. Mckinnon AD, Duggan S, Nichols PD, Rimmer MA, Semmens $\mathrm{G}$, Robino B. The potential of tropical paracalanid copepods as live feeds in aquaculture. Aquaculture 2003; 223:89-106.

121. Helland S, Nejstgaard JC, Fyhn HJ, Egge JK, Båmstedt U. Effects of starvation, season, and diet on the free amino acid and protein content of Calanus finmarchicus fermales. Mar Biol 2003; 143:297-306.

122. Hamre K, Harboe T. Artemia enriched with high n-3 HUFA may give a large improvement in performance of Atlantic halibut (Hippoglossushippoglossus L.) larvae. Aquaculture 2008; 277:239-243.

123. Shields RJ, Lupatsch I. Algae for aquaculture and animal feeds. J Anim Sci 2012; 21:23-37. 